\title{
Keanekaragaman Hayati di Lahan Rehabilitasi Taman Nasional Meru Betiri Dan Implikasi Kebijakannya: Kasus Desa Wonoasri
}

\author{
Alvian Febry Anggana ${ }^{1}$, S. Andy Cahyono ${ }^{2}$ dan C. Yudi Lastiantoro ${ }^{3}$ \\ ${ }^{123}$ Balai Penelitian dan Pengembangan Teknologi Pengelolaan Daerah Aliran Sungai Jl. A. Yani PO BOX \\ 295 Surakarta, Jawa Tengah \\ Email: ${ }^{1}$ angga.kshe43@gmail.com ${ }^{2}$ sandycahyono@yahoo.co.id, ${ }^{3}$ lastiantoro@yahoo.co.id
}

\begin{abstract}
ABSTRAK
Pasca penjarahan dan perusakan lahan hutan pada Kawasan Taman Nasional Meru Betiri. Pemerintah telah melakukan upaya pengembalian kawasan ke kondisi semula. Berbagai upaya dilakukan oleh pihak Taman Nasional Meru Betiri dengan melibatkan masyarakat dalam kegiatan rehabilitasi lahan. Pihak Taman Nasional Meru Betiri memberikan pendampingan dan bantuan bibit kepada masyarakat untuk ikut serta dan bertanggung-jawab melaksanakan penanaman hingga perawatan bibit agar program kegiatan berjalan dengan baik. Salah satu indikator keberhasilan rehabilitasi lahan yaitu peningkatan jumlah jenis tanaman di lahan rehabilitasi. Tujuan penelitian ini adalah menganalisis tingkat keanekaragaman jenis dan kekayaan jenis pada masing-masing lahan rehabilitasi (Wonoasri, Bonangan, Donglo, dan Pletes) setelah dilakukan penanaman dan perawatan di lahan tersebut. Metode yang digunakan menggunakan yaitu kombinasi jalur garis berpetak sepanjang 100-200 m pada setiap lokasi pengambilan data vegetasi. Analisis vegetasi dengan menghitung frekwensi jenis, kerapatan jenis, dominasi jenis, indek nilai penting, indek keanekaragaman jenis, indeks kekayaan jenis dan pola penyebaran. Hasil penelitian menunjukkan bahwa Terdapat 14 jenis vegetasi dalam 11 famili pada 4 plot pengamatan dan tanaman nangka (Artocarpus heterophyllus) yang umum ditemukan dan menunjukkan kemampuan adaptasinya dan tanaman ini dibutuhkan oleh masyarakat. Berdasarkan hasil penelitian menunjukkan bahwa nilai INP pada plot Wonoasri yaitu Pete (Parkia speciosa) sebesar 103.27\%, plot Bonangan yaitu Nangka (Artocarpus heterophyllus) sebesar 154.18\%, plot Donglo yaitu Nangka (Artocarpus heterophyllus) sebesar 133.22\%, dan Pletes yaitu Nangka (Artocarpus heterophyllus) sebesar 262.41\%. Untuk itu, perlu dilakukan penambahan jenis baru diutamakan jenis asli dan pemadatan jarak tanam pada setiap plot rehabilitasi. Pemadatan jarak tanam diharapkan agar nilai keanekaragaman dan kekayaan jenis di lahan rehabilitasi dapat meningkat, sehingga keberhasilan dari kegiatan rehabilitasi dapat terlihat.
\end{abstract}

Kata kunci: Hutan, Keanekaragaman Hayati, Taman Nasional, Vegetasi, Rehabilitasi

\begin{abstract}
After the looting and destruction of forest land in the Merubetiri National Park area were efforts to restore the area to its original condition. The government has made efforts torestore the area to its original condition. Various efforts were made by The Meru Betiri National Park involving the community in land rehabilitation activities. One indicator of the success of land rehabilitation is increasing biodiversity. The purpose of this study was to analyze the level of species diversity and species richness in each rehabilitation land (Wonoasri, Bonangan, Donglo, and Pletes) after planting and maintaining them. The method used uses a 100-200 m striped line combination at each location for vegetation data collection. Vegetation analysis by calculating type frequency, species density, species dominance, important value index, species diversity index, species richness index and distribution pattern. The results showed that there were 14 types of vegetation in 11 families in 4 common observation plots and jackfruit plants (Artocarpus heterophyllus) and showed adaptability and these plants were needed by the community. Based on the results of the study, the INP value of the Wonoasri plot was $103.27 \%$ Pete (Parkia speciosa), Bonangan plot was Jackfruit (Artocarpus heterophyllus) of 154.18\%, Donglo plot of Jackfruit (Artocarpus heterophyllus) was 133.22\%, and Jackfruit Pletes (Artocarpus heterophyllus) of $262.41 \%$. For this reason, it is necessary to do new types of enhancements and compaction of spacing on each rehabilitation plot so that the value of diversity and species richness can increase, so that the success of rehabilitation can be seen.
\end{abstract}

Keywords:Forest, Biodiversity, National Park, Vegetation, Rehabilitation

Citation: Anggana, A. F., Cahyono, S. A., dan Lastiantoro, C. Y. (2019). Keanekaragaman Hayati di Lahan Rehabilitasi Taman Nasional Meru Betiri Dan Implikasi Kebijakannya: Kasus Desa Wonoasri. Jurnal Ilmu Lingkungan, 17(2), 283290,doi:10.14710/jil.17.2.283-290 


\section{Pendahuluan}

Pasca penjarahan dan perusakan lahan hutan pada Kawasan Taman Nasional Merubetiri (TNMB) di era reformasi tahun 1998, dilakukan upaya pengembalian kawasan ke kondisi semula (Aliadi, 2010; BPPTPDAS, 2016; 2017). Berbagai upaya dilakukan diantaranya dengan melibatkan masyarakat dalam rehabilitasi lahan Taman Nasional Merubetiri. Upaya pelibatan masyarakat dengan pemberdayaan ini pada awalnya dikarenakan ketidakmampuan TN Meru Betiri yang baru terbentuk dan upaya meredakan konflik saat itu (BPPTPDAS, 2016; 2017; Nurochmat et al, 2017).

$$
\text { Sependapat dengan pandangan }
$$

Puspaningrum dan Agustina (2014) bahwa pemberdayaan di TNMB pada dasarnya ialah untuk: a) mengurangi tuntutan kebutuhan masyarakat sekitar TNMB terhadap sumberdaya hayati di kawasan hutan melalui peningkatan ekonomi di luar kawasan; b) Sarana meningkatkan pendapatan alternatif masyarakat di luar hutan; c) meningkatkan potensi ketahanan pangan dan membangun kesejahteraan masyarakat desa di luar hutan

Beberapa wilayah TNMB berbatasan dengan masyarakat berupa pemukiman penduduk dan perkebunan dalam kawasan TNMB. Hal ini merupakan tantangan perlunya melibatkan masyarakat dalam kegiatan rehabilitasi lahan pasca penjarahan di TNMB. Kebutuhan pangan dan lahan pertanian membuat system agroforestri diharapkan dapat secara perlahan-lahan mengembalikan lahan rehabilitasi kembali ke awalnya.

Penerapan agroforestri merupakan cara mengolah lahan yang bisa digunakan untuk menjawab masalah yang muncul dikarenakan perubahan lahan dan sekaligus juga untuk mengantisipasi masalah pangan (Amin et al, 2016). Sistem agroforestri diyakini dapat menjadikan lahan terlantar dan terdegradasi menjadi produktif dan dapat memulihkan kualitas lingkungan (Nuridal et al, 2018). Atangana et al. (2014) juga mengemukakan adanya interaksi positif dalam sistem agroforestri seperti fungsi naungan, sumber biomassa, konservasi tanah dan air, dan sumber pakan.

Maurapey, (2013) dan Nugroho dan Yassir (2017) mengungkapkan bahwa dalam pengelolaan dan pemanfaatan sumberdaya lahan, akan timbul permasalahan jika kegiatan yang dilakukan tidak sesuai arah tujuan pengelolaan yang direncanakan sebelumnya. Temuan BPPTPDAS (2016; 2017) menunjukkan bahwa bagi petani, tujuan yang diharapan dari pengelolaan lahan rehabilitasi tersebut adalah peningkatan pendapatan dan kesejahteraan ekonomi. Pada pihak lain, BTN Merubetiri menginginkan lahan rehabilitasi dapat memenuhi kaidah konservasi dan keanekaragaman hayati.

Pemenuhan prinsip perbaikan ekosistem pada lahan rehabilitasi menjadi salahsatu hal yang penting dari tujuan kegiatan di lahan rehabilitasi tidak hanya semata-mata untuk menata, memulihkan, dan memperbaiki lahan dan vegetasi yang rusak untuk dapat berfungsi kembali sesuai peruntukannya saja, tetapi juga harus mampu memperbaiki dan memulihkan komposisi jenis dan struktur komunitas ekosistem hutan tersebut (Mc Donald, et al, 2016; Kusmana dan Melyanti, 2017). Sail D, et al (2004) bependapat bahwa konsep penelitian mengenai keanekaragaman hayati haruslah dapat mencari tahu jenis apa saja yang berada di lokasi tersebut, kemudian mampu menilai pentingnya suatu jenis dan mampu mengidentifikasikan langkah-langkah yang dibutuhkan untuk menjaga jenis tersebut di masa depan.

Namun, temuan Hasibuan et al (2017) dan Hakim et al (2018) menunjukkan bahwa konservasi keanekaragaman hayati di taman nasional belum menunjukkan hasil yang memuaskan. Selain itu, kegiatan di lahan rehabilitasi TNMB belum diketahui dengan pasti dampak dari program ini terhadap komposisi jenis dan struktur vegetasi di Taman Nasional Meru Betiri. Selain itu, salah satu indikator keberhasilan rehabilitasi lahan kawsana konservasi adalah peningkatan keanekaragaman hayati. Berdasarkan uraian tersebut, tujuan penelitian ini adalah mengetahui menganalisis tingkat keanekaragaman dan kekayaan jenis pada lahan rehabilitasi pasca kegiatan rehabilitasi berserta implikasi kebijakannya.

\section{Metode Penelitian \\ 1. Pengumpulan data \\ a. Lokasi penelitian}

Penelitian di lakukan pada lahan rehabilitasi Taman Nasional Meru Betiri yang terletak di Desa Wonoasri, Kecamatan Tempurejo ,Kabupaten Jember. Lahan rehabilitasi ini pada awalnya merupakan lahan pasca penjarahan kawasan hutan dalam pangkuan TNMB yang dilakukan upaya penenaman tanaman keras atau pohon. Pada kegiatan penelitian ini dilakukan penghitungan vegetasi pada 4 lokasi di Wonoasri yaitu di Lokasi Wonoasri, Bonangan, Donglo dan Pletes. Penentuan lokasi tersebut dilakukan dengan teknik purposive sampling, yaitu pengambilan sampel sebagai sumber data dengan pertimbangan khusus (Sugiyono, 2013). Pertimbangan diambilnya lokasi tersebut berdasarkan pertimbangan merupakan lahan rehabilitasi yang dinilai berhasil oleh TNMB.

\section{b. Alat dan bahan}

Alat dan bahan yang digunakan dalam kegiatan penelitian ini yaitu; peta petak kerja, alat tulis, tallysheet, patok, pita ukur/phiband, kompas, GPS, golok, haga, buku identifikasi, papan penekan, plastik, label, pisau, kamera, dan Ms Office 2013. Adapun bahan yang digunakan, yaitu; label, tali tambang/rafia, kantung plastik, kertas koran, alkohol, dan kertas karton.

\section{c. Teknik pengumpulan data vegetasi}

Analisis vegetasi dilakukan pada plot rehabilitasi dengan menggunakan metode kombinasi jalur garis berpetak sepanjang 100-200 m setiap 
lokasi pengambilan data vegetasi. Penentuan arah plot berbentuk horisontal-vertikal atau sejajar dengan aliran sungai. Metode analisis vegetasi berdasarkan dari metode yang telah dikeluarkan oleh Kusmana (1997) yaitu pengukuran vegetasi yang dibagi ke dalam petak ukur dengan luas berdasarkan pertumbuhan vegetasi, diantaranya: $20 \times 20 \mathrm{~m}^{2}$ (Tingkat pohon), $10 \times 10 \mathrm{~m}^{2}$ (Tingkat Tiang) $5 \times 5 \mathrm{~m}^{2}$ (Tingkat Pancang), dan 2x2 $\mathrm{m}^{2}$ (Semai).

\section{Pengolahan dan Analisis Data Vegetasi}

Data vegetasi rehabilitasi hutan yang berhasil dikumpulkan selanjutnya dianalisis dengan dihitung nilai-nilai : frekuensi jenis, kerapatan jenis, dominasi jenis, indeks nilai penting, indeks keanekaragaman jenis, indeks kekayaan jenis dan pola penyebaran.

\section{a. Indeks Nilai Penting}

Struktur dan komposisi vegetasi merupakan suatu hal yang perlu diketahui untuk mendapatkan INP. Maka, setiap petak ukur harus dilakukan pengukuran analisis dominansi, frekuensi dan kerapatan untuk setiap jenis tumbuhan.

Menurut Kusmana (1997)Perhitungan dilakukan dengan menggunakan rumus sebagai berikut :

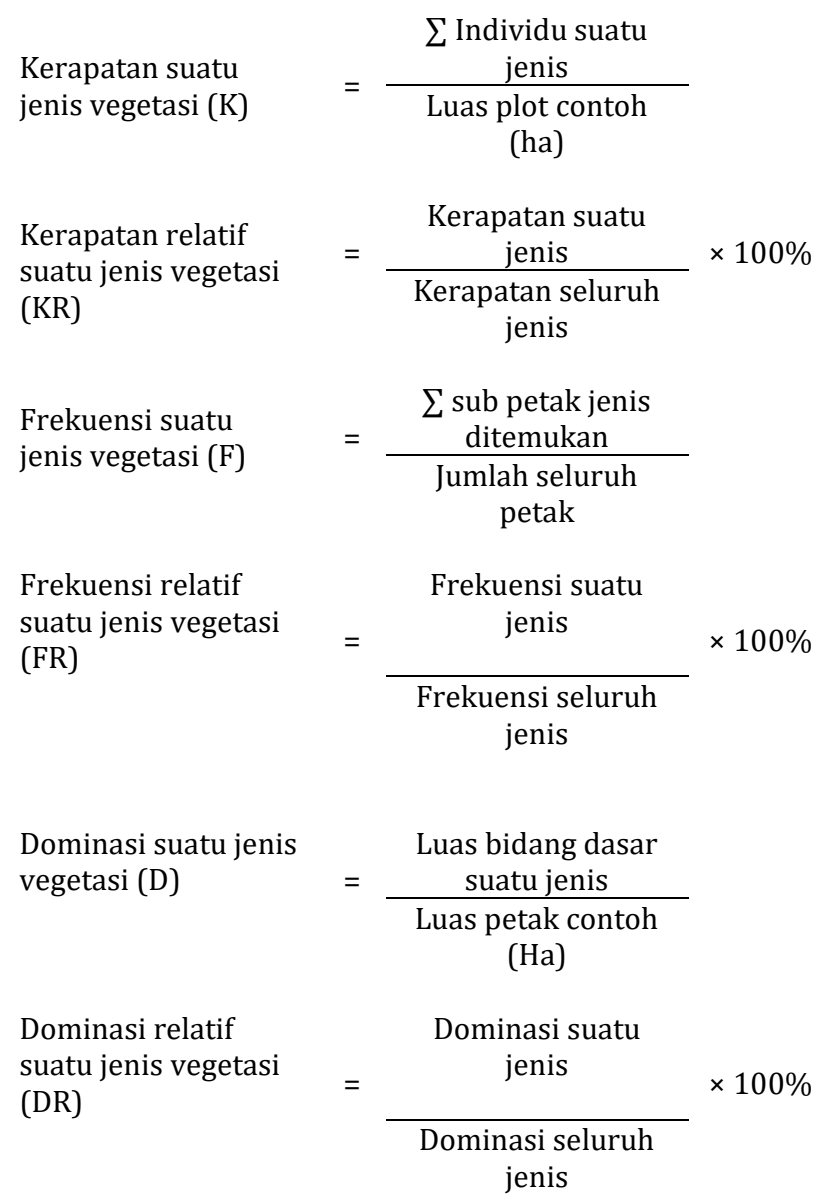

Indeks Nilai Penting (INP)

INP pada tingkat semai dan pancang, melalui penjumlahan Kerapatan Relatif (KR) dan Frekuensi
Relatif (FR), INP=KR+FR. INP tiang dan pohon, melalui penjumlahan Kerapatan Relatif (KR), Frekuensi Relatif (FR) dan Dominansi Relatif, INP=KR+FR+DR. Perhitungan Total INP dihitung pada setiap plot pengamatan analisis vegetasi plot pengamatan analisis vegetasi. Nilai INP kemudian mampu menggambarkan kondisi vegetasi di ekosistem tersebut.

\section{b. Tingkat Keanekaragaman Jenis}

Magurran (1988) dalam penelitannya mengenai keanekaragaman jenis menggunakan Indeks Keanekaragaman Shannon (H'). Adapun persamaannya sebagai berikut:

$\mathbf{H}=-\Sigma[\mathbf{P i} \ln \mathbf{P i}] \quad$ Dimana $\mathrm{P}=\frac{\mathrm{Ni}}{\mathrm{N}}$

Keterangan :

$\mathrm{H}^{\prime}$ : Indeks Keanekaragaman Shannon

$\mathrm{Ni}$ : Jumlah individu suatu jenis

$\mathrm{N}$ : jumlah individu seluruh jenis

- Nilai $H^{\prime} \geq 3$ menunjukkan bahwa keanekaragaman jenisnya tinggi,

- nilai $\mathrm{H}^{\prime}$ antara 2 - 3 menunjukkan bahwa keanekaragaman jenisnya pada kondisi sedang

- dan apabila nilai $\mathrm{H}^{\prime}<2$ menunjukkan kondisi keanekaragaman jenisnya rendah.

\section{c. Kekayaan jenis (Species richness)}

Analisis kekayaan jenis dalam suatu plot ukur, bisa dihitung dengan pendekatan Indeks kekayaan jenis Margaleft. Adapun persamaan sebagai berikut:

$\mathrm{R}_{1}=\frac{\mathrm{S}-1}{\operatorname{Ln} N}$

Keterangan:

$\mathrm{R} 1$ = Indeks kekayaan Margaleft

$\mathrm{S}=$ Jumlah jenis

$\mathrm{N}$ = Jumlah individu

Indeks kekayaan Margalleft (R1) adalah indeks yang memberikan informasi terkait kondisi jenis suatu komunitas, dimana nilainya dipengaruhi oleh jumlah jenis dan jumlah individu pada lokasi pengukuran. Berdasarkan (Magurran, 1988) ada 3 kriteria kekayaan suatu komunitas vegetasi, diantaranya: kekayaan jenis vegetasi tergolong rendah apabila R1 kurang dari 3.5, kekayaan jenis tergolong sedang jika R1 = 3,5- 5,0, dan apabila R1 lebih dari 5,0 maka kekayaan jenisnya tergolong tinggi.

\section{Hasil penelitian}

\section{Kekayaan Jenis Tumbuhan Berdasarkan Lokasi Rehabilitasi di TNMB}

Hasil penelitian menunjukkan bahwa kekayaan jenis tumbuhan pada empat (4) lahan rehabilitasi TNMB sebanyak 254 individu dari 11 famili. Kekayaan jenis tumbuhan lahan rehabilitasi tersaji pada tabel1. 
Tabel 1. Kekayaan jenis tumbuhan lahan rehabilitasi di empat (4) lokasi rehabilitasi

\begin{tabular}{lcccc}
\hline $\begin{array}{l}\text { Lokasi } \\
\text { Rehabi- } \\
\text { litasi }\end{array}$ & $\begin{array}{c}\text { Jumlah } \\
\text { individu }\end{array}$ & $\begin{array}{c}\text { Jumlah } \\
\text { Individu } \\
(\%)\end{array}$ & $\begin{array}{c}\text { Jumlah } \\
\text { Famili }\end{array}$ & $\begin{array}{c}\text { Famili } \\
(\%)\end{array}$ \\
\hline Wonoasri & 103 & 40.55 & 10 & 90.90 \\
Bonangan & 57 & 22.45 & 7 & 63.64 \\
Donglo & 50 & 19.69 & 6 & 54.54 \\
Pletes & 44 & 17.32 & 2 & 18.18 \\
\hline
\end{tabular}

Pada plot pengamatan rehabilitasi Wonoasri, sekitar $40.55 \%$ individu dan $90.90 \%$ jumlah famili. Jenis-jenis vegetasi yang terdapat pada Wonoasri, diantaranya: Kelengkeng (Dimacarpus longan), Kedawung (Parkia roxburghii), Nangka (Artocarpus heterophyllus), Pete (Parkia speciosa), Pinang (Areca catechu), Jambu (Psidium guajava), Kemiri (Aleurites moluccana), Mengkudu (Morinda citrifolia), Asem (Tamarindus indica), Mangga (Mangifera indica), dan Duwet (Syzygium cumini). Plot ini memiliki kekayaan jenis terbanyak, hal ini disebabkan oleh beberapa faktor lain :

a. Berdasarkan hasil wawancara dari salah satu petani penggarap di plot rehabilitasi Wonoasri menunjukkan bahwa kesadaran petani untuk menjaga pertumbuhan tanaman di plot rehabilitasi berjalan dengan baik. Hal ini ditunjukkan dari hasil pengukuran analisis vegetasi ditemukan sedikit tanaman yang mati. Lebih dari itu, Masyarakat

Wonoasri mampu bekerjasama dengan pihak pengelola TNMB dalam menjaga pertumbuhan tanaman rehabilitasi. Masyarakat Wonoasri di sekitar lahan tidak memanfaatkan tanaman rehabilitasi sebagai pakan ternak. Peternak sudah memanfaatkan rumput gajah sebagai pakan rumput.

b. Sedangkan kekayaan jenis tumbuhan paling rendah ditemukan di lokasi rehabilitasi Pletes sebanyak 44 individu dari 2 famili. Hal inidisebabkan kondisi sosial masyarakat di Desa Pletes berbeda dengan wilayah lainnya. Peternak Pletes untuk memenuhi kebutuhan pangan ternaknya masih bergantung pada tanaman rehabilitasi. -Oleh karena itu, pertumbuhan tanaman rehabilitasi terganggu kemudian mati. Hasil analisis vegetasi menunjukkan masih ditemukan banyak tanamanyang tidak -mempunyai kanopi yang sempurna serta- bedeng tanaman yang sudah kosong.

\section{Analisis Vegetasi Pohon}

Komposisi pohon hasil analisis vegetasi pada plot pengamatan lahan rehabilitasi TNMB disajikan Tabel berikut.

Tabel 2. Komposisi Pohon Hasil Analisis Vegetasi

\begin{tabular}{lllllll}
\hline No & Nama Latin & Nama Lokal & Wonoasri & Bonangan & Donglo & Pletes \\
\hline 1 & $\begin{array}{l}\text { Dimacarpus } \\
\text { longan }\end{array}$ & Kelengkeng & $\sqrt{ }$ & & & \\
2 & Parkia roxburghii & Kedawung & $\sqrt{ }$ & & $\sqrt{ }$ & $\sqrt{ }$ \\
3 & $\begin{array}{l}\text { Artocarpus } \\
\text { heterophyllus }\end{array}$ & Nangka & $\sqrt{ }$ & $\sqrt{ }$ & $\sqrt{ }$ & \\
4 & Parkia speciosa & Pete & $\sqrt{ }$ & $\sqrt{ }$ & $\sqrt{ }$ & \\
5 & Areca catechu & Pinang & $\sqrt{ }$ & $\sqrt{ }$ & & \\
6 & Psidium guajava & Jambu & $\sqrt{ }$ & & \\
7 & Aleurites & Kemiri & $\sqrt{ }$ & & $\sqrt{ }$ \\
& moluccana & & & & \\
8 & Morinda citrifolia & Mengkudu & $\sqrt{ }$ & $\sqrt{ }$ & \\
9 & Tamarindus indica & Asem & $\sqrt{ }$ & $\sqrt{ }$ & $\sqrt{ }$ \\
10 & Mangifera indica & Mangga & $\sqrt{ }$ & $\sqrt{ }$ & $\sqrt{ }$ \\
11 & Syzygium cumini & Duwet & $\sqrt{ }$ & & $\sqrt{ }$ \\
12 & Durio zibethinus & Duren & & $\sqrt{ }$ & \\
13 & Artocarpus altilis & Sukun & & & \\
14 & Artocarpus & Kluwih & & & \\
& camansi & & & & \\
\hline
\end{tabular}

Berdasarkan Tabel 2. terdapat 14 jenis vegetasi yang masuk kedalam 11 famili, hanya jenis nangka (Artocarpus heterophyllus) yang dapat ditemukan pada 4 plot pengamatan analisis vegetasi. Keberadaan nangka pada keempat plot tersebut dapat dijadikan sebagai acuan bagi Pihak Taman Nasional Meru Betiri dalam kegiatan rehabilitasi berikutnya namun jenis-jenis lain diharapkan bisa dimunculkan guna meningkatkan kekayaan jenis pada lahan rehabilitasi terutama jenis tanaman lokal.

Nilai kerapatan suatu jenis merupakan petunjuk mengenai jumlah individu pada luasan tertentu, nilai kerapatan memberikan informasi mengenai jumlah jenis vegetasi pada tiap-tiap plot pengamatan. Namun, nilai kerapatan belum memberikan gambaran terkait distribusi individu pada suatu plot pengamatan. Sedangkan, nilai frekuensi memberikan informasi mengenai distribusi individu. Frekuensi tertinggi ditemukan pada plot pengamatan Pletes ditemukan pada jenis Nangka (Artocarpus heterophyllus) yaitu sebesar $71.43 \%$. Hal ini menunjukkan bahwa jenis Nangka mampu beradaptasi dengan baik pada plot tersebut. Keberhasilan setiap jenis tumbuhan 
dipengaruhi oleh kemampunnya beradaptasi maksimal terhadap lingkungan dimana jenis tersebut hidup. Hal ini sesuai dengan pernyataan Balakrisnan et al (1994) menyatakan bahwa beberapa jenis vegetasi di hutan tropika teradaptasi dengan kondisi di naungan kanopi, tengah, dan di atas kanopi yang intensitas cahayanya berbeda-beda.

Tabel 3. Hasil Perhitungan INP Pada Plot Pengamatan Wonoasri

\begin{tabular}{llllll}
\hline Nama Latin & Nama Lokal & KR(\%) & FR(\%) & DR(\%) & INP(\%) \\
\hline Dimacarpus longan & Kelengkeng & 0.97 & 2.38 & 0.22 & 3.57 \\
Parkia roxburghii & Kedawung & 9.71 & 9.52 & 24.97 & 44.2 \\
Artocarpus heterophyllus & Nangka & 25.24 & 23.81 & 23.01 & 72.06 \\
Parkia speciosa & Pete & 41.75 & 28.57 & 32.95 & 103.27 \\
Areca catechu & Pinang & 2.91 & 7.14 & 1.28 & 11.33 \\
Psidium guajava & Jambu & 1.94 & 2.381 & 1.86 & 6.18 \\
Aleurites moluccana & Kemiri & 0.97 & 2.381 & 1.07 & 4.421 \\
\hline Morinda citrifolia & Mengkudu & 7.77 & 9.52 & 5.83 & 23.12 \\
Tamarindus indica & Asem & 5.83 & 7.14 & 5.59 & 18.56 \\
Mangifera indica & Mangga & 1.94 & 4.76 & 2.73 & 9.43 \\
Syzygium cumini & Duwet & 0.97 & 2.38 & 0.47 & 3.82 \\
\hline
\end{tabular}

Tabel 4. Hasil Perhitungan INP Pada Plot Pengamatan Bonangan

\begin{tabular}{llllll}
\hline Nama Latin & Nama Lokal & KR(\%) & FR(\%) & DR(\%) & INP(\%) \\
\hline Mangifera indica & Mangga & 19.30 & 16 & 23.88 & 59.18 \\
Tamarindus indica & Asem & 5.26 & 8 & 6.20 & 19.46 \\
Durio zibethinus & Duren & 1.75 & 4 & 1.57 & 7.32 \\
Morinda citrifolia & Mengkudu & 5.26 & 12 & 6.35 & 23.61 \\
Artocarpus heterophyllus & Nangka & 57.90 & 40 & 56.28 & 154.18 \\
Parkia speciosa & Pete & 8.77 & 16 & 5.36 & 30.13 \\
Areca catechu & Pinang & 1.75 & 4 & 0.36 & 6.11 \\
\hline
\end{tabular}

Tabel 5. Hasil Perhitungan INP pada plot pengamatan Donglo

\begin{tabular}{llllll}
\hline Nama Latin & Nama Lokal & KR(\%) & FR(\%) & DR(\%) & INP(\%) \\
\hline Tamarindus indica & Asem & 2 & 6.25 & 2.35 & 10.6 \\
Durio zibethinus & Duren & 4 & 12.5 & 7.68 & 24.18 \\
Parkia roxburghii & Kedawung & 2 & 6.25 & 4.32 & 12.57 \\
Artocarpus heterophyllus & Nangka & 50 & 31.25 & 51.97 & 133.22 \\
Parkia speciosa & Pete & 36 & 31.25 & 24.64 & 91.89 \\
Artocarpus altilis & Sukun & 2 & 6.25 & 5.03 & 13.28 \\
Syzygium cumini & Duwet & 4 & 6.25 & 4.01 & 14.26 \\
\hline
\end{tabular}

Tabel 6. Hasil perhitungan INP pada plot pengamatan Pletes

\begin{tabular}{llllll}
\hline Nama Latin & Nama Lokal & KR(\%) & FR(\%) & DR(\%) & INP(\%) \\
\hline $\begin{array}{l}\text { Artocarpus } \\
\text { heterophyllus }\end{array}$ & Nangka & 95.45 & 71.43 & 95.53 & 262.41 \\
$\begin{array}{l}\text { Areca catechu } \\
\text { Artocarpus camansi }\end{array}$ & Pinang & 2.27 & 14.29 & 1.02 & 17.58 \\
\hline
\end{tabular}

Nilai dominansi jenis vegetasi berdasarkan dari besaran diameter batang pada setiap jenis, sehingga nilai dominansi sangat dipengaruhi oleh kerapatan dan jumlah diameter masing-masing jenis. Dominansi tertinggi ditemukan pada plot Pletes (Tabel. 6) yaitu Nangka (Artocarpus heterophyllus) sebesar $95.53 \%$ dan Kelengkeng (Dimacarpus longan) sebesar $0.22 \%$ yang ditemukan pada plot 1 . Dominansi berfungsi untuk mengetahui kondisi suatu jenis tertentu yang mendominasi pada suatu lahan. Berdasarkan hasil analisis tersebut menunjukkan bahwa Nangka memiliki jumlah individu dan besaran batang yang tertinggi daripada jenis lainnya.

Indeks Nilai Penting (INP) adalah hasil penjumlahan dari ketiga parameter yaitu : Kerapatan Relatif, Frekuensi Relatif, dan Dominansi Relatif. Berdasarkan hasil penelitian menunjukkan bahwa nilai INP pada plot 1 yaitu Pete (Parkia speciosa) sebesar $103.27 \%$, plot Bonangan yaitu Nangka (Artocarpus heterophyllus) sebesar $154.18 \%$, plot Donglo yaitu Nangka (Artocarpus heterophyllus) sebesar 133.22\%, dan Pletes yaitu Nangka (Artocarpus heterophyllus) sebesar 262.41\%. 
Menurut Sundarapandian dan Swany (2000) menyebutkan bahwa indeks nilai penting merupakan salah satu parameter yang menggambarkan mengenai peranan jenis yang bersangkutan dalam komunitasnya pada lokasi plot penelitian.

Berdasarkan hasil penelitian (Tabel 7) menunjukan bahwa plot Wonoasri memiliki jumlah jenis tertinggi dibandingkan plot pengamatan lainnya. Plot Wonoasri juga memiliki nilai indeks Keanekaragaman Jenis dan Indeks Kekayaan Jenis tertinggi. Walaupun demikian, kedua indeks tersebut terindikasi masuk dalam kategori rendah. Hal ini menunjukkan bahwa perlu dilakukannya penambahan jenis baru dan pemadatan jarak tanam pada setiap plot rehabilitasi sehingga nilai keanekaragaman dan kekayaan jenis dapat meningkat.

Tabel 7. Tingkat Keanekaragaman Jenis dan Kekayaan Jenis

\begin{tabular}{llcl}
\hline \multicolumn{4}{c}{ Lokasi } \\
Rehabilitasi & $\begin{array}{l}\text { Jumlah } \\
\text { Jenis } \\
(\boldsymbol{\Sigma})\end{array}$ & $\begin{array}{l}\text { Indeks } \\
\text { Keanekaragaman } \\
\text { Jenis (H') }\end{array}$ & $\begin{array}{l}\text { Indeks } \\
\text { Kekayaan } \\
\text { Jenis }\end{array}$ \\
\hline Wonoasri & 11 & 1.844 & 2.15 \\
Bonangan & 7 & 1.44 & 1.48 \\
Donglo & 7 & 1.46 & 1.53 \\
Pletes & 3 & 0.46 & 0.53 \\
\hline
\end{tabular}

\section{Implikasi kebijakan}

Kegiatan pada lahan rehabilitasi berupaya mengembalikan kondisi seperti sebelum terjadinya penjarahan lahan. Namun, keberhasilan dilihat dari keanekaragaman hayati menunjukkan hasil yang relatif rendah. Kondisi ini karena petani masih memilih tanaman yang dapat meningkatkan kesejahteraanya secara monoculture dan tanaman keras atau kayu yang tetap dipertahankan merupakan tanaman yang tidak menganggu tanaman pertaniannya. Penggunaan jenis jenis lokal cukup berdampak positif pada lahan rehabilitasi. Hasil penelitian Yassir dan Omon (2009) pada rehabilitasi lahan bekas tambang menunjukkan bahwa penggunaan jenis-jenis lokal berdampak positif bagi kegiatan konservasi keanekaragaman hayati karena jenis tersebut mampu mempercepat proses suksesi alami. Selain itu, penggunaan jenis lokal dapat menjaga keaslian genetik jenis-jenis tersebut dan mampu meningkatkan keberhasilan kegiatan penanaman. Selain itu jenis lokal relatif lebih adaptif terhadap lingkungan setempat. Sebaliknya, untuk tanaman eksotik yang bersifat invasif sebaiknya dilarang karena tanaman tersebut akan menekan pertumbuhan dan penyebaran tanaman lokal yang dapat mengancam keberhasilan program rehabilitasi atau reklamasi (Jordan et al., 2008; Norton, 2009; Vilà, 2011). Beberapa penyebab rendahnya keanekaragaman hayati pada lahan rehabilitasi TNMB adalah pemilihan jenis yang adaptif terhadap kondisi lahan yang belum optimal. Pemilihan bibit masih berdasarkan stok bibit yang ada di pasaran belum mampu mengoptimalkan jenis asli yang berada di dalam TNMB. Lebih dari itu, Hasil dari kegiatan monitoring perkembangan pertumbuhan tanaman hingga kondisi lahan juga belum terdokumentasi dengan baik.

Monitoring dan evaluasi (monev) merupakan salah satu indikator yang sangat memengaruhi keberhasilan program restorasi/rehabilitasi lahan. Hal ini dikarena dari kegiatan monev faktor-faktor yang memengaruhi keberhasilan ataupun kegagalan suatu program restorasi/rehabilitasi bisa dipelajari (Bernhardt et al., 2007; Kondolf et al., 2007; Lovett et al., 2007; Morandi, Piégay, Lamouroux, \& Vaudor, 2014). Namun, kegiatan monev untuk program pemulihan dan perbaikan lahan ini relatif jarang dilakukan karena kriteria kesuksesan suatu program restorasi/rehabilitasi relatif sulit diprediksi (Suding, 2011).

Hasil analisis vegetasi menunjukkan bahwa nilai indeks Keanekaragaman Jenis dan Indeks Kekayaan Jenis masuk dalam kategori rendah. Untuk meningkatkan keanekaragaman hayati dan kekayaan jenis perlu dilakukannya penambah jenis tanaman baru serta pemadatan jarak tanam pada setiap plot rehabilitasi. Pemilihan tanaman tersebut perlu mempertimbangkan keanekaragaman jenis, keinginan masyarakat, dan tujuan yang akan dicapai dalan lahan rehabilitasi. Kebijakan insentif dan disinsentif perlu dikembangkan dengan mengkaitkan nilai keanekaragaman hayati dengan insentif tertentu dan pemberian disinsentif bagi lahan yang memiliki keanekaragaman hayati rendah.

\section{Kesimpulan dan Saran}

\section{a. Kesimpulan}

Pada lahan rehabilitasi ditemukan 14 jenis vegetasi dalam 11 famili pada 4 plot pengamatan dan tanaman nangka (Artocarpus heterophyllus) yang umum ditemukan. Tanaman Nangka memiliki kemampuan adaptasi tinggi dan dibutuhkan oleh masyarakat. Wonoasri memiliki jumlah jenis tertinggi dibandingkan plot pengamatan lainnya. Oleh karena itu, Wonoasri memiliki nilai indeks Keanekaragaman Jenis dan Indeks Kekayaan Jenis tertinggi dibandingkan plot lainnya. Namun, kedua indeks tersebut masih terindikasi masuk dalam kategori rendah. Salah satu cara yang perlu dilakukan adalah melakukan penambahan jenis baru dan pemadatan jarak tanam pada setiap plot rehabilitasi sehingga diharapkan nilai keanekaragaman dan kekayaan jenis dapat meningkat.

\section{Saran}

Penelitian ini menunjukkan bahwa kondi vegetasi pada lahan rehabilitasi berdasarkan nilai indeks Keanekaragaman Jenis dan Indeks Kekayaan Jenis masuk dalam kategori rendah. Oleh karena itu, Pihak Taman nasional Meru Betiri untuk bisa melakukan penambahan jenis baru serta pemadatan jarak tanam pada setiap plotnya agar nilai 
keanekaragaman dan kekayaan jenis dapat meningkat. Penambahan jenis di lahan rehabilitasi diharapkan bisa memilih jenis lokal yang berada di dalam kawasan TNBM. Sebagai pertimbangan, Jenis lokal tersebut mampu mendukung perekonomian masyarakat.

\section{Ucapan Terima Kasih}

Penelitian ini adalah bagian dari kegiatan penelitian yang berjudul Resolusi konflik tenurial di Taman nasional Meru Betiri, Jember. Ucapan terima kasih kami sampaikan kepada Kepala Taman Nasional Meru Betiri, ketua kelompok tani dan petani lahan rehabilitasi.

\section{DAFTAR PUSTAKA}

Aliadi, A. 2010. Developing partnership for conservation at Meru Betiri National park. Technical Report no 6. ITTO, Cifor, Latin, dan Taman Nasional Meru Betiri. Jember.

Amin, M., I. Rachman dan S. Ramlah. 2016. Jenis agroforestri dan orientasi pemanfaatan lahan di Desa Simora Kecamatan Gumbasa Kabupaten Sigi. Warta Rimba, 4(2): 97-104.

Atangana A, Khasa D, Chang S, Degrande A. 2014. Tropical Agroforestri. Springer. 380 pages.

Balakrishnan, M., R. Borgstrom and S.W.Bie. 1994. Tropical Ecosystem, a synthesis of tropical Ecology and Conservation. International Science Publisher. New York.

Bernhardt, E. S., Sudduth, E. B., Palmer, M. A., Allan, J. D., ...., dan Lave, R. (2007). Restoring rivers one reach at a time: Results from a survey of US river restoration practitioners. Restoration Ecology, 15(3): 482-493.

BPPTPDAS. 2016. Resolusi konflik tenurial di Taman Nasional Meru Betiri Jember. Laporan hasil penelitian. Badan Penelitian Pengembangan dan Inovasi, Kementerian Lingkungan Hidup dan Kehutanan. Solo. Tidak dipublikasikan.

BPPTPDAS. 2017. Resolusi konflik tenurial di Taman Nasional Meru Betiri Jember. Laporan hasil penelitian. Badan Penelitian Pengembangan dan Inovasi, Kementerian Lingkungan Hidup dan Kehutanan. Solo. Tidak dipublikasikan.

Hakim, L., I. Aldianoveri., I.K. Bangsa dan D.A. Guntoro. 2018. Peran dan dampak konflik tenurial kehutanan bagi pengelolaan keanekaragaman hayati di kawasan cagar biosfer di Jawa Timur. Jurnal Hutan Tropis, 6 (1): 43-51.

Hasibuan, S.H., A. Sunkar dan Y. Santosa. 2017. Identifikasi peubah social ekonomi penentu keberhasilan konservasi keanekaragaman hayati. Media Konservasi, 22 (2): 156-163.

Heru. 2016. Rekayasa Vegetatif Untuk Mengurangi Resiko Longsor. Surakarta: Balai Penelitian dan Pengembangan Teknologi Pengelolaan Daerah Aliran Sungai.

Jordan, N. R., Larson, D. L., dan Huerd, S. C. 2008. Soil modification by invasive plants: Effects on native and invasive species of mixed-grass prairies. Biological Invasions, 10(2): 177-190.

Kondolf, G. M., Anderson, S., Lave, R., Pagano, L., Merenlender, A., dan Bernhardt, E. 2007. Two decades of river restoration in California: What can we learn? Restoration Ecology, 15(3): 516-523.
Kusmana, C dan A.R. Melyanti. 2017. Keragaman komposisi jenis dan struktur vegetasi pada kawasan hutan lindung dengan pola PHBM di BKPH Tampomas, KPH Sumedang, Perum Perhutani divisi regional Jawa Barat dan Banten. Jurnal Silvikultur Tropika, 8 (2) Agustus 2017: 123-129.

Kusmana. (1997). Metode Survey Vegetasi. Bogor: Institut Pertanian Bogor.

Lovett, G. M., Burns, D. A., Driscoll, C. T., ......., dan Haeuber, R. 2007. Who needs environmental monitoring? Frontiers in Ecology and the Environment, 5(5): 253-260.

Ludwig, J., \& Reynold, J. (1988). Statistical Ecology. New York: Jhon Wiley and Sons.

Magurran, A. (1988). Statistical Ecology. New York: Jhon Wiley and Sons.

McDonald, T., Gann, G., Jonson, J., dan Dixon, K. 2016. International standards for the practice of ecological restoration - Including principles and key concepts. (First Edition). Washington, DC: Society for Ecological Restoration.

Morandi, B., Piégay, H., Lamouroux, N., dan Vaudor, L. 2014. How is success or failure in river restoration projects evaluated? Feedback from French restoration projects. Journal of Environmental Management, 137: 178-188.

Norton, D. A. 2009. Species invasions and the limits to restoration: Learning from the New Zealand experience. Science, 325(5940): 569-571.

Nugroho, A.W. dan I. Yassir. 2017. Kebijakan penilaian keberhasilan reklamasi lahan pasca tambang batubara di Indonesia. Jurnal Analisis Kebijakan Kehutanan, 14 (2): 121-136

Nuridal, N.L., A. Mulyani, F. Widiastuti dan F. Agus. 2018. Potensi dan model agroforestri untuk rehabilitasi lahan terdegradasi di Kabupaten Berau, Paser dan Kutai Timur, Provinsi Kalimantan Timur. Jurnal Tanah dan Iklim, 42 (1): 13-26..

Nurrochmat, D.R., I.A. Nugroho, Hardjanto, A. Purwadianto, A. Maryusi dan J.T. Erbaugh. 2017. Shifting contestation into cooperation: strategy to incorporate different interest of actors in medicinal plants in Meru Betiri National park, Indonesia. Forest Policy and Economics 83 (2017): 162-168

Puspaningrum, D dan T. Agustina. 2014. Model pembangunan alternative berbasis masyarakat pada Taman Nasional Meru Betiri. Agritop Jurnal Ilmu-Ilmu Pertanian, 12 (2): 188-199. http://jurnal.unmuhjember.ac.id/index.php/AGRIT ROP/article/view/723/591

Sheil, D., Puri, R.K., Basuki, I., Heist, M.V., Wan, M., Liswati, N., Rukmiyati., Sradjono, M.A., Samsoedin, Ismayadi,. Sidiyasa, K., Chrisandini., Permana, Edi., Angi, E.M., Gatzweiler, F., Johnson, B., dan Wijaya, A.2004. Mengeksplorasi Keanekaragaman Hayati Lingkungan dan Pandangan Masyarakat Lokal Mengenai Berbagai Lanskap Hutan. Centre For International Forestry Research. Bogor.

Soerianegara, I., \& Indrawan, A. (1998). Ekologi Hutan Indonesia. Jurusan Manajemen Hutan, Fakultas Kehutanan, Institut Pertanian Bogor.

Suding, K. N. 2011. Toward an era of restoration in ecology: Successes, failures, and opportunities ahead. Annual Review of Ecology, Evolution, and Systematics, 42(1): 465.

Sugiyono. 2013. Metode penelitian kuantitatif, kualitatif dan R\&D. Penerbit Alfabet. Bandung.

Sundarapandian, S.M. and P.S. Swamy. 2000. Forest 
ecosystem structure and composition along an altitudinal gradient in the Western Ghats, South India. Journal Of Tropical Forest Science 12(1): 104123.

Vilà, M., Espinar, J L., Hejda, M., ....., dan Pyšek, P. 2011. Ecological impacts of invasive alien plants: A metaanalysis of their effects on species, communities and ecosystems. Ecology letters, 14(7): 702-708.
Yassir, I dan R. M. Omon. 2009. Pemilihan jenis jenis pohon potensial untuk mendukung kegiatan restorasi lahan tambang melalui pendekatan ekologis. Prosiding Workshop IPTEK Penyelamatan Hutan Melalui Rehabilitasi Lahan Pasca tambang Batubara pp: 64-76. Samarinda: Balai Besar Penelitian Dipterokarpa. 